\title{
Varl-COSI 2018: a forum for research advances in variant interpretation and diagnostics
}

\author{
Yana Bromberg ${ }^{1,2^{*}+}$, Emidio Capriotti $3^{3^{*}+}$ and Hannah Carter ${ }^{4^{*}+}$ \\ From Varl-COSI 2018: identification and annotation of genetic variants in the context of structure, function, and disease \\ Chicago, IL, USA. 08 July 2018
}

\section{Introduction}

Technological advances and decreasing costs of DNA sequencing have created a deluge of genomic data [1-3]. These include millions of genetic variants that require interpretation relative to various traits or diseases. The Variant Interpretation Community Of Special Interest Group (VarI-COSI, formerly VarI-SIG) provides an international forum for researchers to share progress in their work to address the need for strategies to detect, annotate and interpret variants in the context of health and disease. The 8th edition of the VarI-COSI meeting [4-9] was held on July 8th, 2018 at the ISMB meeting in Chicago, Illinois (USA).

This year's meeting of the VarI-COSI featured three keynote talks, 11 research presentations and two industry presentations describing new datasets, bioinformatic methods, and scientific studies aimed at advancing our understanding of genetic variation. In addition, we heard presentations from our sponsors, Variantyx and Qiagen describing technological developments for variant detection and prioritization.

This year, the VarI-COSI was divided into a morning and afternoon session. The morning session began with a keynote by Bonnie Berger describing the potential of genomic crowdsourcing with privacy to significantly boost data availability for genomic studies. Talks in this session described approaches to mine position-specific

\footnotetext{
*Correspondence: yanab@rci.rutgers.edu; emidio.capriotti@unibo.it; hkcarter@ucsd.edu

${ }^{\dagger}$ Yana Bromberg, Emidio Capriotti and Hannah Carter contributed equally to this work.

'Department of Biochemistry and Microbiology, Lipman Hall 218, Rutgers University, New Brunswick, NJ 08901, USA

${ }^{3}$ Department of Pharmacy and Biotechnology (FaBiT), University of Bologna, 40126 Bologna, Italy

${ }^{4}$ Division of Medical Genetics, Department of Medicine, University of

California, San Diego, CA 92093, USA

Full list of author information is available at the end of the article
}

information from the genome to better annotate and study genetic variation. Speakers described using information about protein structure to study variants at protein interaction interfaces, identifying positions involved in the functional tuning of proteins, using signatures of purifying selection to implicate non-coding Mendelian variants, and annotating variants with an expanded set of conservation categories using machine learning.

The afternoon included two additional keynotes. Mona Singh described work studying variation that affects protein interactions with target molecules to gain insights into the pathogenesis of cancer. Olga Troyanskaya described the application of deep learning to predict the effect of single nucleotide variants on the expression of nearby genes. Talks in the afternoon session included statistical developments to improve meta-analysis in GWAS studies in the presence of heterogeneity, new methods for detecting splicing and structural variants, and different approaches using molecular measurements or diverse phenotypes to gain improved insight into the role of genetic variation in disease processes.

We welcome Antonio Rausell from the Institut Imagine, Paris (France) to the VarICOSI organizing committee.

The VarI-COSI executive committee invites the community to provide feedback regarding meeting content and format, as well as to participate in future sessions of the meeting.

\section{Manuscript submission and review}

For this year's VarI-COSI special issue received 12 manuscript submissions. All manuscripts were evaluated by at least two reviewers, selected by a panel of three editors and 25 experts in the field (see Acknowledgements). After 2 rounds of review 11 manuscripts were accepted for publication. These presented novel strategies for implicating biological functions underlying diverse human 
phenotypes [10], detecting new genes associated with cardiovascular disease [11], inferring the impact of variants on protein stability [12], predicting the effects of variants in membrane proteins [13], at post-translational modification sites [14], on mRNA translation [15] and on DNA ionization [16].

Other manuscripts describe the development methods for improving variant calling [17] and analysis of structural variants [18] and studying the effects of somatic mutations in cancer on metabolism [19] and tumor interaction with the immune system [20].

The complete program of VarI-COSI meeting 2018 with presentation and poster abstracts is available at http://varicosi.biofold.org/2018/schedu.html .

\section{Further developments}

We are working to organize the next VarI-COSI meeting (ISMB/ECCB 2019; Basel, Switzerland; July 24th, 2019). Further information about this coming meeting is available on our website (http://varicosi.biofold.org/).

\section{Acknowledgments}

We thank Frank Schacherer from Qiagen and Alex Kaplun from Variantyx for their financial support. We acknowledge the editorial staff of BioMed Central for their help with releasing this issue. We would like to extend special thanks for all help to the ISMB organizational committee and specifically Steven Leard and Jeremy Hennig.

We also thank the invited speakers: Bonnie Berger, (Massachusetts Institute of Technology, Cambridge, MA), Mona Singh (Princeton University, Princeton, $\mathrm{NJ}$ ) and Olga Troyanskaya (Princeton University, Princeton, NJ).

Finally, we are very grateful for the patience and help of our colleagues around the world who reviewed the submitted manuscripts. The Varl-COSI 2018 special issue would has not be possible without them: Matteo Brilli (University of Milan, Italy), Bin Chen (Michigan State University, East Lansing, USA), Isidro Cortes Cirano (Harvard University, Cambridge USA), Xavier de La Cruz (Vall d'Hebron Institute of Research, Barcelona, Spain). Francisco Garcia (Centro de Investigacion Principe Felipe, Valencia, Spain), Lisbeth Guethlein (Stanford University), Jared Johnson (Cornell University, Ithaca, USA), Panos Katsonis (Baylor College of Medicine, Huston, USA), Alain Laederach (University of North Carolina, Chapel Hill, USA), Monkol Lek (Yale University New Haven, USA), Salvatore Loguercio (Univesity of California San Diego, USA), Fabio Marroni (University of Udine, Italy), Pablo Minguez (Fundación Jiménez Díaz, Madrid, Spain), Alberto Riva (University of Florida, Gainesville, USA) Jairo Rocha (University of Balearic Islands, Palma de Mallorca Spain), Andreas Schueller (Pontificia Universidad Católica de Chile, Chiile), Shaolei Teng (Howard University, Washington, USA), and other anonymous reviewers.

\section{About this supplement}

This article has been published as part of BMC Genomics Volume 20 Supplement 8, 2019: Proceedings of Varl-COSI 2018: identification and annotation of genetic variants in the context of structure, function, and disease: genomics. The full contents of the special issue are available online at https:// bmcgenomics.biomedcentral.com/articles/supplements/volume-20supplement-8, https://bmcmedgenomics.biomedcentral.com/articles/ supplements/volume-12-supplement-6 and https://bmcbioinformatics. biomedcentral.com/articles/supplements/volume-20-supplement-14.

\section{Authors' contributions}

$\mathrm{YB}, \mathrm{EC}$ and $\mathrm{HC}$ wrote the manuscript. All the authors read and approved the manuscript.

\section{Funding}

This supplement has not been supported by sponsorship.
Availability of data and materials

No data are associated to this manuscript.

Ethics approval and consent to participate

Not applicable

\section{Consent for publication}

Not applicable

\section{Competing interests}

The authors declare that they have no competing interests.

\section{Author details}

${ }^{1}$ Department of Biochemistry and Microbiology, Lipman Hall 218, Rutgers University, New Brunswick, NJ 08901, USA. ${ }^{2}$ Department of Genetics, Lipman Hall 218, Rutgers University, New Brunswick, NJ 08901, USA. ${ }^{3}$ Department of Pharmacy and Biotechnology (FaBiT), University of Bologna, 40126 Bologna, Italy. ${ }^{4}$ Division of Medical Genetics, Department of Medicine, University of California, San Diego, CA 92093, USA.

Published: 16 July 2019

\section{References}

1. Capriotti E, Nehrt NL, Kann MG, Bromberg Y. Bioinformatics for personal genome interpretation. Brief Bioinform. 2012;13(4):495-512.

2. 1000 Genomes Project Consortium, Abecasis GR, Auton A, Brooks LD, MA DP, Durbin RM, Handsaker RE, Kang HM, Marth GT, GA MV. An integrated map of genetic variation from 1,092 human genomes. Nature. 2012; 491(7422):56-65.

3. Capriotti E, Ozturk K, Carter H. Integrating molecular networks with genetic variant interpretation for precision medicine. Wiley Interdiscip Rev Syst Biol Med. 2019;11(3):e1443

4. Bromberg Y, Capriotti E. SNP-SIG meeting 2011: identification and annotation of SNPs in the context of structure, function, and disease. BMC Genomics. 2012;13(Suppl 4):S1.

5. Bromberg Y, Capriotti E. Thoughts from SNP-SIG 2012: future challenges in the annotation of genetic variations. BMC Genomics. 2013:14(Suppl 3):S1.

6. Bromberg Y, Capriotti E. SNP-SIG 2013: from coding to non-coding--new approaches for genomic variant interpretation. BMC Genomics. 2014; 15(Suppl 4):S1

7. Bromberg Y, Capriotti E. SNP-SIG 2013: the state of the art of genomic variant interpretation. Bioinformatics. 2015;31(3):449-50.

8. Bromberg Y, Capriotti E. Varl-SIG 2014--from SNPs to variants: interpreting different types of genetic variants. BMC Genomics. 2015;16(Suppl 8):11.

9. Bromberg Y, Capriotti E, Carter H. Varl-SIG 2015: methods for personalized medicine - the role of variant interpretation in research and diagnostics. BMC Genomics. 2016;17(Suppl 2):425.

10. Babbi G, Martelli P, Casadio R. PhenPath: a tool for characterizing biological functions underlying different phenotypes. BMC Genomics. 2019;20(Suppl 8):S6.

11. Glicksberg B, Amadori L, Akers N, Sukhavasi K, Franzén O, Li L, Belbin G, Ayers K, Shameer K, Badgeley M, et al. Integrative analysis of loss-of-function variants in clinical and genomic data reveals novel genes associated with cardiovascular traits. BMC Medical Genomics. 2019;12(Suppl 6):S2. https:// doi.org/10.1186/s12920-019-0542-3.

12. Montanucci L, Capriotti E, Frank Y, Ben-Tal N, Fariselli P. DDGun: an untrained method for the prediction of protein stability changes upon single and multiple point variations. BMC Bioinformatics. 2019. https://doi.org/10.1186/s12859-0192923-1.

13. Orioli $T$, Vihinen $M$. Benchmarking membrane proteins: subcellular localization and variant tolerance predictors. BMC Genomics. 2019. https:// doi.org/10.1186/s12864-019-5865-0.

14. Simpson C, Zhang B, Hornbeck P, Gnad F. Systematic analysis of the intersection of disease mutations with protein modifications. BMC Medical Genomics. 2019;12(Suppl 6):S3. https://doi.org/10.1186/s12920-019-0543-2.

15. Polte C, Wedemeyer D, Wagner J, Oliver K, Bijvelds M, Mahoney J, de Jonge $\mathrm{H}$, Sorscher $\mathrm{E}$, Ignatova Z. Assessing cell-specific effects of genetic variation using tRNA microarrays. BMC Medical Genomics. 2019;20(Suppl 8):S2. https://doi.org/10.1186/s12864-019-5864-1.

16. Pucci F, Rooman M. More insights into the relation between DNA ionization potentials, single base substitutions and pathogenic mutations. BMC Genomics. 2019;20(Suppl 8):S5. https://doi.org/10.1186/s12864-019-5867-y. 
17. Field M, Burgio G, Chuah A, Al Shekaili J, Simon F, Cook M, Andrews DT Recurrent miscalling of missense variation from short-read genome sequence data information. BMC Medical Genomics. 2019;20(Suppl 8):S1. https://doi.org/10.1186/s12864-019-5863-2.

18. Neerman N, Faust G, Meeks N, Modai S, Kalfon L, Falik-Zaccai T, Kaplun A. A clinically validated whole genome pipeline for structural variant detection and analysis. BMC Medical Genomics. 2019;20(Suppl 8):S4. https://doi.org/10. 1186/s12864-019-5866-z.

19. Ascolani G, Lio' P. Modeling breast cancer progression to bone: how driver mutation order and metabolism matter. BMC Medical Genomics. 2019; 12(Suppl 6):S1. https://doi.org/10.1186/s12920-019-0541-4.

20. Castro A, Ozturk K, Pyke R, Xian S, Zanetti M, Carter H. Elevated neoantigen levels in tumors with somatic mutations to B2M and HLA. BMC Medical Genomics. 2019;12(Suppl 6):S4. https://doi.org/10.1186/s12920-019-0544-1.

\section{Publisher's Note}

Springer Nature remains neutral with regard to jurisdictional claims in published maps and institutional affiliations.

- fast, convenient online submission

- thorough peer review by experienced researchers in your field

- rapid publication on acceptance

- support for research data, including large and complex data types

- gold Open Access which fosters wider collaboration and increased citations

- maximum visibility for your research: over $100 \mathrm{M}$ website views per year

At BMC, research is always in progress. 